\title{
ANALYSIS OF SINGLE PARTICLE IMPACT BREAKAGE DISTRIBUTION FUNCTIONS OF A COLEMANITE ORE BY DROP WEIGHT TECHNIQUE
}

\author{
(KOLEMANIT CEVHERININ TEK TANE DARBE KIRILMA DAĞILIMI

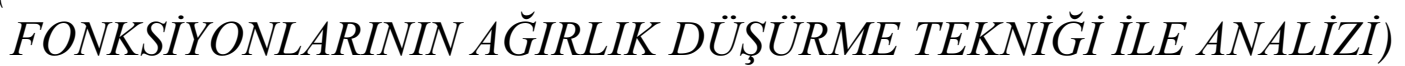

\section{Ömürden GENÇ ${ }^{1}$}

\begin{abstract}
ÖZ
Kolemanit cevherinin tek tane darbe kırılma dağılımı fonksiyonları Narayanan [1] tarafından geliştirilen standard test yöntemleri ve veri değerlendirme metodolojisi kullanılarak tahmin edilmiştir. $\mathrm{Bu}$ amaçla, modifiye edilmiş JK Tech ağırlık düşürme test aletinin [2] manuel versiyonu kullanılmıştır. Kırılma testi sonuçları özgül ufalama enerjisi (Ecs) ve t10 boyut dağılımı parametresi ile temsil edilen darbe kırılması ürün inceliği arasındaki ilișkinin kurulmasında kullanılmıştır. Napier Munn vd., [3] tarafindan verilen Ecs-t10 ufalama modeli kırılma testi sonuçları için sınanmıştır. Test sonuçları Ecs-t10 ufalama modeline başarılı bir şekilde uyum sağlamıştır. t-aile eğrisi yaklaşımı [1, 4, 5] özgül kırılma fonksiyonlarının oluşturulmasında kullanılmıştır. t10-tn aile eğrileri modellenmiş ve eğrilerin ampirik regresyon denklemleri kırıcı modelleri için kırılma fonksiyonunun farklı enerji seviyelerinde oluşturulması için önerilmiştir.
\end{abstract}

Anahtar Kelimeler: Kolemanit, Ufalama, Modelleme, Kırılma fonksiyonu, Ağırlık düşürme testi

\section{ABSTRACT}

Single particle impact breakage distribution functions of a colemanite ore were estimated using the standard test methods and data evaluation methodology developed by Narayanan [1]. For this purpose, a modified manual version of a JK Tech drop weight test device [2] was used. Breakage test results were used to establish the relationship between specific comminution energy (Ecs) and impact breakage product fineness which was represented by the size distribution parameter t10. Ecs-t10 comminution model given by Napier Munn et.al [3] was validated for the breakage test results. Ecs-t10 comminution model was successfully fitted to the breakage test results. $t$-family curve approach $[1,4,5]$ was used to re-construct specific breakage functions. t10-tn family curves were modelled and empirical regression equations were proposed to reconstruct breakage functions at different impact energy levels which could be used in models of crushers.

Keywords: Colemanite, Comminution, Modeling, Breakage function, Drop weight test

\footnotetext{
1 Muğla Sitkı Koçman Üniversitesi, Mühendislik Fakültesi, Maden Mühendisliği Bölümü, MUĞLA, ogenc@mu.edu.tr (Ömürden GENÇ)
} 


\section{INTRODUCTION}

More than $60 \%$ of the world's Boron compounds reserves are in Turkey. Turkey's commercially recoverable boron reserves are colemanite, ulexite and tincal. Colemanite is an important ore of boron and is a commercially important borate mineral with a chemical composition of $\mathrm{Ca}_{2} \mathrm{~B}_{6} \mathrm{O}_{11} .5 \mathrm{H}_{2} \mathrm{O}$. It has many industrial uses, like manufacturing of heat resistant glass, cosmetic, in the production of glass, fibers, heat resistant materials, nuclear reactors, fire retardants, catalysis and detergents, etc. [6].

Crushing of the ore is the first processing step to convert borate ores into either sodium borates or boric acid. Single particle breakage test methods were widely used for the understanding of the complex nature of particle breakage took in industrial size reduction machines to estimate crushing and grinding performance. Single particle breakage information is used to describe how ore particles break inside the comminution machines and to model size reduction so that, throughput, power draw and product size distribution can be predicted to find the optimum operational conditions for grinding. Tests can be grouped into three main classes depending on the breakage mechanism; single impact, double impact (dynamic loading) and slow compression. These tests were applied by many researchers for the investigation of input energy-size reduction relationships of ores to model crushing and grinding in comminution machines. A general review of single particle test applications and their results were presented by Narayanan [4]. Considering the impact breakage mechanism in size reduction machines, most commonly used double impact testers are twin-pendulum and drop-weight devices. They provided practical informations on the impact breakage of individual particles of different ores types [1, 3, 7]. Drop weight test method, in which a single particle is subjected to breakage between two solid surfaces, was found wide application in material characterization [1, 3, 8, 9]. Different version of a drop weight tester known as the ultra-fast load cell was used for the understanding of the fracture and deformation characteristics of particles under impact loading $[10,11,12,13]$.

Material breakage is usually characterised by the breakage distribution (appearance) function in comminution models which were used to estimate crushing or grinding performance of the machines. Specific breakage functions were used to reflect material breakage properties on specific breakage rates which is one of the comminution machine model parameter. Some of the researchers $[4,14,15,16]$ assumed that, breakage function of materials is independent of initial particle size and process conditions and in some cases input energy level [17]. On the other hand, many studies proved the versa case [7, 8, 9,12, 18, 19, 20, 21]. Although many methods are suggested in the literature for the measurement of breakage distributions experimentally, it is usually difficult to represent the breakage of materials by a standart method due to the mathematical formulation and non-normalizable breakage. For this reason, single-particle breakage tests such as twin-pendulum and drop-weight techniques were used in developing standard procedures for the calculation of breakage functions $[1,4,5,7,22,23,24$, $25]$ to model comminution machines.

In this study, it was aimed to analyse the single particle breakage functions of a colemanite ore by drop weight test technique. Standard test procedures and data evaluation methodology [1] were applied for the determination of impact breakage functions using breakage test results of various size fractions at different impact energy levels. Energy-t10 relationship and tn-family curves were modelled to estimate empirical breakage functions for the ore. Specific 
breakage functions were proposed to be used in models of crushers crushing the colemanite ore. Test results also provided useful insights for Turkish colemanite ore impact breakage.

\section{MATERIALS AND METHODS}

\subsection{Description of the Drop Weight Device}

A photograph of the drop weight device with its design specifications is given in Figure 1. It mainly comprises a steel anvil made from steel alloy, plate shaped drop weight head, an electromagnet through which an electromagnetic field is formed so that weights can be hold or released from desired heights. Drop weight device is fitted with a $5.870 \mathrm{~kg}$ fixed head mass which can be extended to $44.16 \mathrm{~kg}$ with a maximum drop height of $51.50 \mathrm{~cm}$ representing a wide energy range. In this experimental set up, plate shaped drop weight is raised to a known height through a mechanical arm and then subjected to free fall onto a particle that is placed on the center of the steel anvil. Breakage area is enclosed by an aluminium casing in order to prevent the losing of the broken fragments during the test.

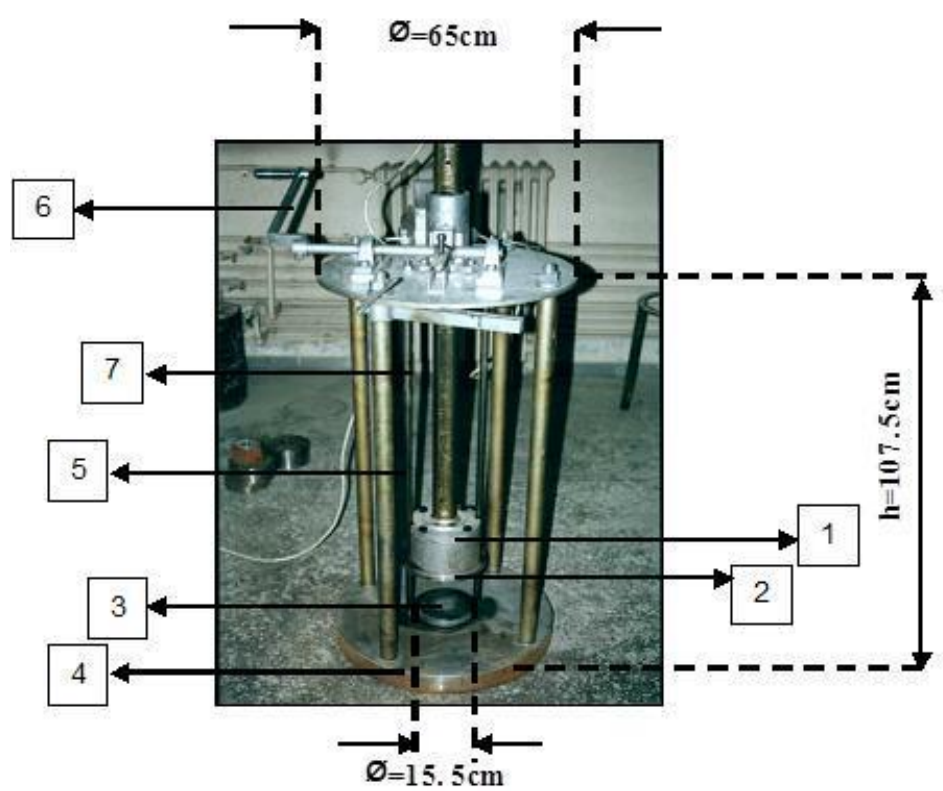

Figure 1. Manual version of JK Tech drop weight test device [26]

In Figure 1;

1-Electromagnetic head

2-Fixed lead head mass $(5.870 \mathrm{~kg})$

3-Steel anvil (Diameter: $15.5 \mathrm{~cm}$ )

4-Steel base

5-Ruler for drop height adjustment

6-Mechanical arm

7-Drop-weight rail 


\subsection{Sample and Laboratory Studies}

Colemanite ore sample was dry sieved to the narrow size fractions of $-28+25.4 \mathrm{~mm}$, $22.4+19 \mathrm{~mm}$ and $-16+13.2 \mathrm{~mm}$ in the sample preparation stage. Particles were selected randomly by using a riffler from each size fraction. Randomly selected particles of each size fraction were subjected to impact breakage from three energy levels. Particles were subjected to impact breakage one by one. Broken fragments were collected and dry sieved on a root 2 sieve series down to $0.038 \mathrm{~mm}$ on a ro-tap sieve shaker for 15 minutes to determine breakage product size distributions. Test specifications are summarized in Table 1. Impact energy supplied by the plate shaped weight is calculated from the equations given by Napier Munn et al. [3].

Table 1. Drop weight test specifications

\begin{tabular}{|c|c|c|c|c|c|}
\hline $\begin{array}{c}\text { Test size } \\
\text { fraction } \\
(\mathrm{mm})\end{array}$ & $\begin{array}{c}\text { Nominal particle } \\
\text { size }(\mathrm{mm})\end{array}$ & $\begin{array}{c}\text { Number of } \\
\text { particles broken } \\
\text { per energy level }\end{array}$ & $\begin{array}{c}\text { Total weight of } \\
\text { particles } \\
\text { (g) }\end{array}$ & $\begin{array}{c}\text { Drop height } \\
\text { (cm) }\end{array}$ & $\begin{array}{c}\text { Specific } \\
\text { impact energy } \\
(\mathrm{kWh} / \mathrm{t})\end{array}$ \\
\hline \multirow{3}{*}{$-28+25.4$} & \multirow{3}{*}{26.67} & 8 & 253.84 & 6.20 & 0.09 \\
\hline & & 8 & 254.13 & 13.5 & 0.20 \\
\hline & & 8 & 252.62 & 21.2 & 0.33 \\
\hline \multirow{3}{*}{$-22.4+19$} & \multirow{3}{*}{20.63} & 15 & 257.12 & 6.20 & 0.16 \\
\hline & & 15 & 261.23 & 13.5 & 0.38 \\
\hline & & 15 & 261.59 & 21.2 & 0.59 \\
\hline \multirow{3}{*}{$-16+13.2$} & \multirow{3}{*}{14.53} & 30 & 140.61 & 6.20 & 0.60 \\
\hline & & 30 & 140.02 & 13.5 & 1.42 \\
\hline & & 30 & 140.58 & 21.2 & 2.25 \\
\hline
\end{tabular}

\section{RESULTS AND DISCUSSIONS}

\subsection{Particle Size Distributions}

Impact breakage product size distributions of test size fractions were analyzed on log-log scales to demonstrate the effects of size and impact energy. Breakage size distributions are given in Figures 2 to 4 which indicated a systematic size reduction progress with an increase in impact energy level for each test size fraction. 


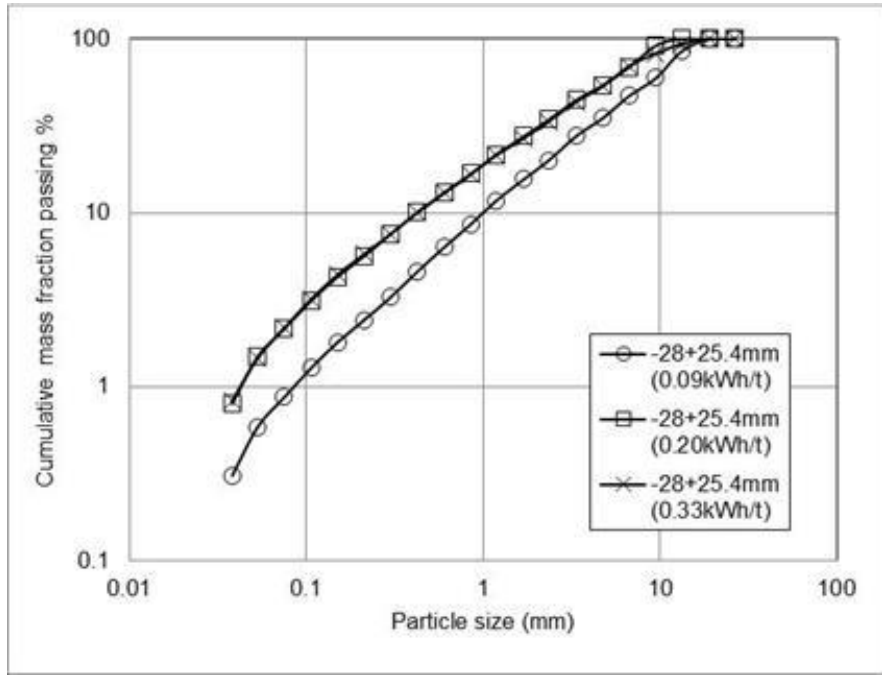

Figure 2. Particle size distributions of particles in the size fraction of $-28+25 \mathrm{~mm}$ at different impact energy levels

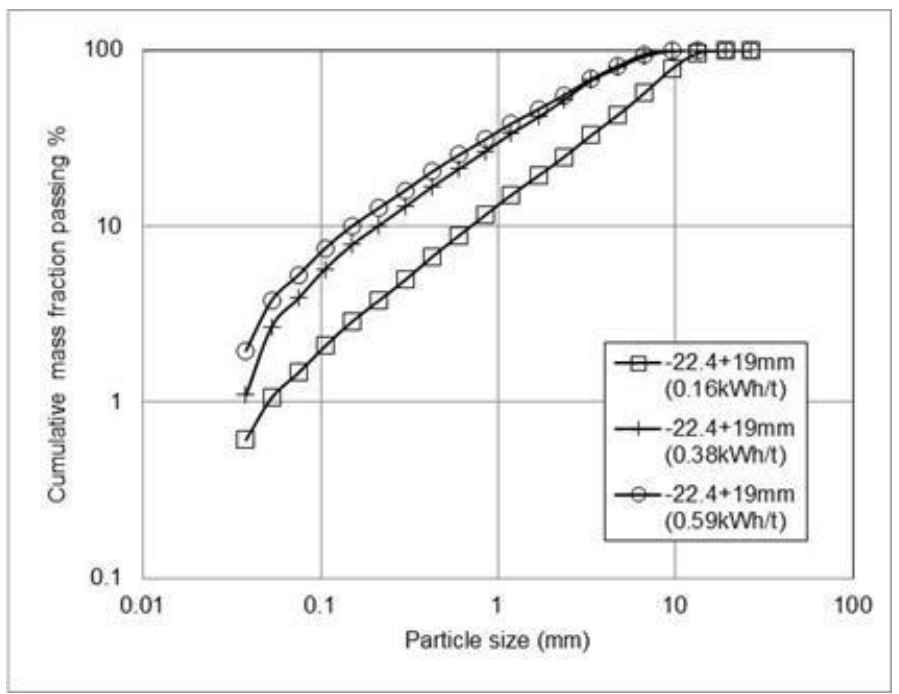

Figure 3. Particle size distributions of particles in the size fraction of $-22.4+19 \mathrm{~mm}$ at different impact energy levels 


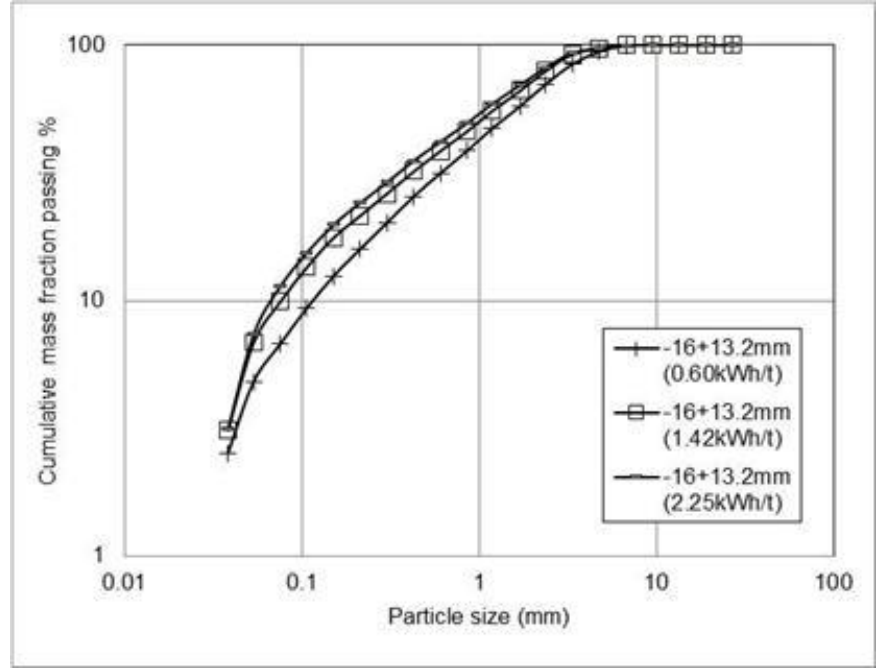

Figure 4. Particle size distributions of particles in the size fraction of $-16+13.2 \mathrm{~mm}$ at different impact energy levels

\section{2. t-curves}

Narayanan and Whiten [27, 28] developed a useful approach by which the results of double impact tests can be evaluated through a series of breakage distribution parameters represented by $t$ numbers. Narayanan [1] defined a series of breakage product size distribution parameters represented by tn $(n=2,4,10,25,50,75)$. th is the percentage passing $1 / \mathrm{n}$ times the original (nominal) particle size which can be obtained for each breakage product size distribution. The values of tn can be plotted against the corresponding t10 to establish curves that smooth the size distributions and allow the computation of the breakage size distribution for any value of t10 within the range of the data. 110 number is an indication of the fineness of broken particle size. In this way, impact breakage fineness of materials can be determined through a single distribution parameter at any specific comminution energy level.

\subsection{Energy-t10 Comminution Model}

Particle size distribution parameter, t10 can be plotted against energy and this curve is often fitted by Equation 1 [29, 30].

$$
\mathrm{t} 10=\mathrm{Ax}[1-\exp (-\mathrm{bxEcs})]
$$

$\mathrm{A}$ and $\mathrm{b}$ are material parameters and Ecs is the specific comminution energy in Equation 1. A is the limiting value of 110 . The product Axb which is the slope of the relation, characterizes the hardness of the ore. Low values of Axb indicating that, more energy is needed for an equivalent amount of breakage as discussed by Napier Munn et.al. [3]. It is noted that, Axb has a physical meaning in the region where there is data and is often found to have more stable values than A or b separately [26]. Experimental t10 values as a function of specific comminution energy levels were fitted to the Ecs-t10 relationship in Eq.1. Impact breakage model for the colemanite ore is given by Equation $2 . \mathrm{R}^{2}$ of the overall model fit was 0.96 . Axb value was determined as 220.19. Overall fitting results are given in Figure 5. Equation 2 normalizes the particle size effect in breakage function estimation. 


$$
\mathrm{t} 10=62.74 \mathrm{x}\lfloor 1-\exp (-3.51 \times \mathrm{Ecs})\rfloor
$$

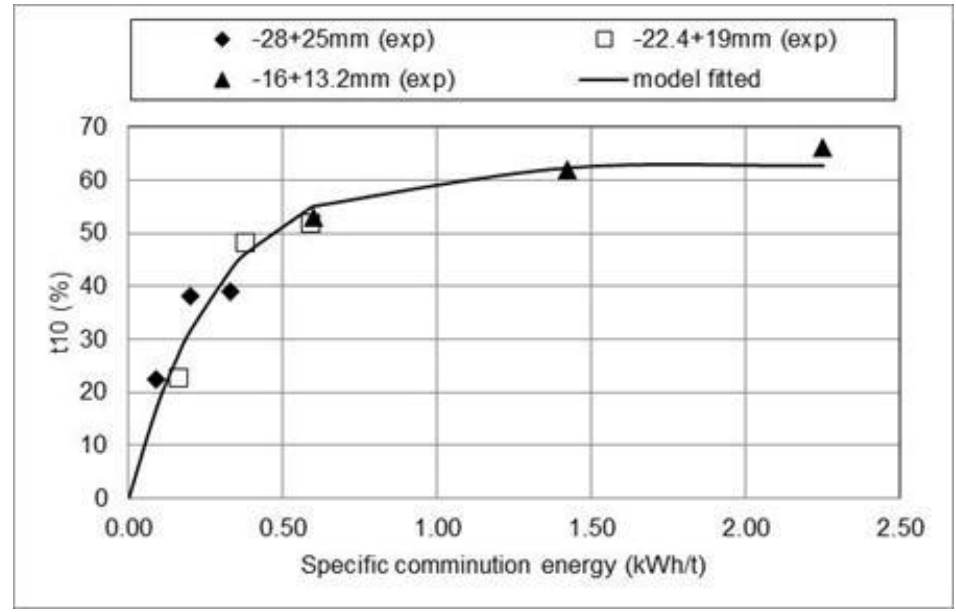

Figure 5. Overall Ecs-10 relationship

Specific comminution energy versus t10 relationships were fitted to Equation 1 for each particle size fraction to show the effect of particle size. Estimated breakage model parameters for each test size fraction are tabulated in Table 2. Model fitted relationships are given in Figure 6. Plots given in Figure 6 indicated that, impact breakage of particles in the size fraction of $-28+25 \mathrm{~mm}$ could not produce fine particles as compared to the other test size fractions at energy levels higher than approximately $0.5 \mathrm{kWh} / \mathrm{t}$. Although the energy was increased, t10 did not change much for particles of $-28+25 \mathrm{~mm}$ fraction. Particle size effect on the relationship could be observed at energy levels lower than $0.5 \mathrm{kWh} / \mathrm{t}$ such that, as the particle size was decreased, lower 110 value was obtained for a constant specific comminution energy level. In other words, smaller particles required higher specific comminution energy levels for the same degree of breakage. Relationship between nominal particle size and Axb breakage parameter was investigated in Figure 6 . The relationship could be defined by an exponential function given in Figure 6. Axb values indicated that, particles in the size fraction $-28+25 \mathrm{~mm}$ broke more easily as compared to the other test size fractions. Difference in the breakage behaviour could be linked to the mineralogical and textural properties of the size fractions.

Table 2. Particle size specific impact breakage parameters

\begin{tabular}{|c|c|c|c|c|c|}
\hline $\begin{array}{c}\text { Test size } \\
\text { fraction }(\mathrm{mm})\end{array}$ & $\begin{array}{c}\text { Nominal } \\
\text { particle size } \\
(\mathrm{mm})\end{array}$ & $\mathrm{A}$ & $\mathrm{b}$ & $\mathrm{R}^{2}$ & Axb \\
\hline$-28+25$ & 26.46 & 42.23 & 9.30 & 0.99 & 392.52 \\
\hline$-22.4+19$ & 20.63 & 63.15 & 3.20 & 0.99 & 202.29 \\
\hline$-16+13.2$ & 14.53 & 64.83 & 2.79 & 1.00 & 220.19 \\
\hline
\end{tabular}




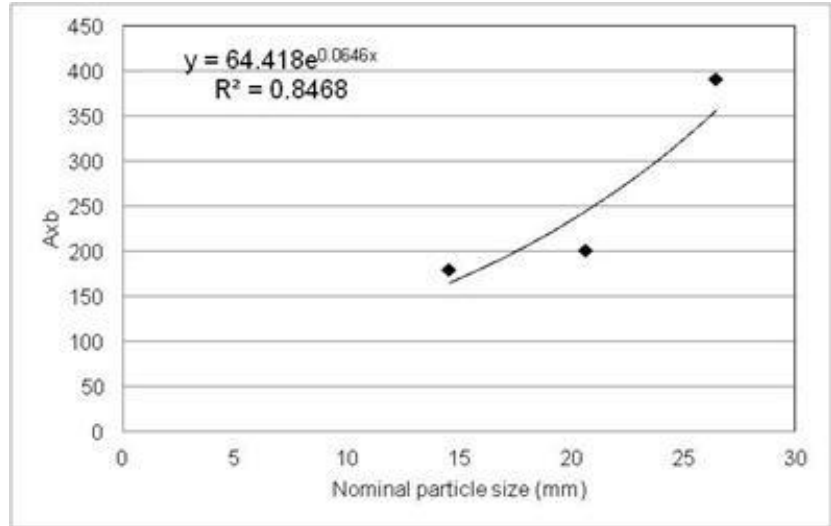

Figure 6. Relationship between particle size and Axb

\subsection{Breakage Function Re-construction}

The relationships between t10 and tn parameters are reported as a one parameter family of curves (tn family) by Narayanan [1]. King [31] defined tn family curves as breakage function reconstruction (master) curves. Details of the breakage function reconstruction from t10-tn family of curves were discussed by Narayanan and Whiten [27] for ore particles. The tn family curves established are given in Figure 7 with the regression trendlines. Empirical regression equations of th family curves are given in Table 3. Figure 7 provides models for the breakage function that are based on the impact energy for practical comminution equipment modelling work.

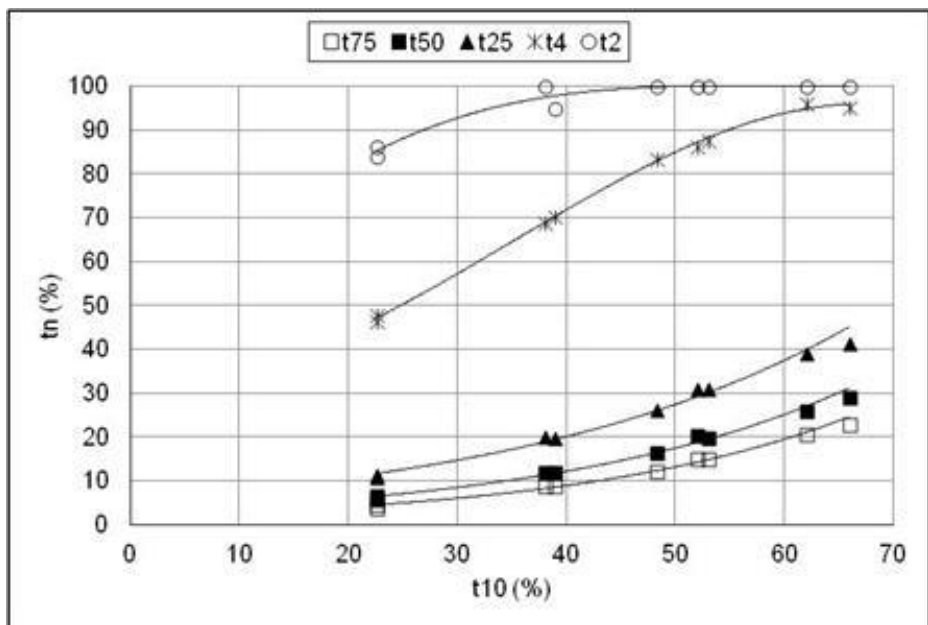

Figure 7. Typical trends of tn-family curves 
Table 3. Empirical regression equations of t10-tn family curves

\begin{tabular}{|l|l|}
\hline Regression equations & $\mathrm{R}^{2}$ \\
\hline $\mathrm{t} 2=0.0003(\mathrm{t} 10)^{3}-0.0575(\mathrm{t} 10)^{2}+3.3568(\mathrm{t} 10)+34.904$ & 0.95 \\
\hline $\mathrm{t} 4=-0.0005(\mathrm{t} 10)^{3}+0.0507(\mathrm{t} 10)^{2}-0.3094(\mathrm{t} 10)+33.802$ & 1.00 \\
\hline $\mathrm{t} 25=5.7273 \mathrm{e}^{0.0313(\mathrm{t} 10)}$ & 0.99 \\
\hline $\mathrm{t} 50=2.8347 \mathrm{e}^{0.0363(\mathrm{t} 10)}$ & 0.99 \\
\hline $\mathrm{t} 75=1.8388 \mathrm{e}^{0.0393(\mathrm{t} 10)}$ & 0.99 \\
\hline
\end{tabular}

Maximum particle size of the jaw crusher feed was assumed to be $28 \mathrm{~mm}$ which is the maximum test particle size and normalized breakage functions were estimated using the regression equations of t10-tn family curves for different specific comminution energy levels. Specific breakage functions are given in Figure 8. These functions could be used to relate breakage rates to available energies in modelling of comminution machines. The difference between the breakage functions were found to be high at low impact energy levels such as $0.25 \mathrm{kWh} / \mathrm{t}$ and $0.50 \mathrm{kWh} / \mathrm{t}$ as demonstrated in Figure-8. However, as the level of energy was increased similar breakage functions were obtained. No more considerable fine particles would be produced above energy levels higher than $1 \mathrm{kWh} / \mathrm{t}$ as breakage function curves become closer to each other.

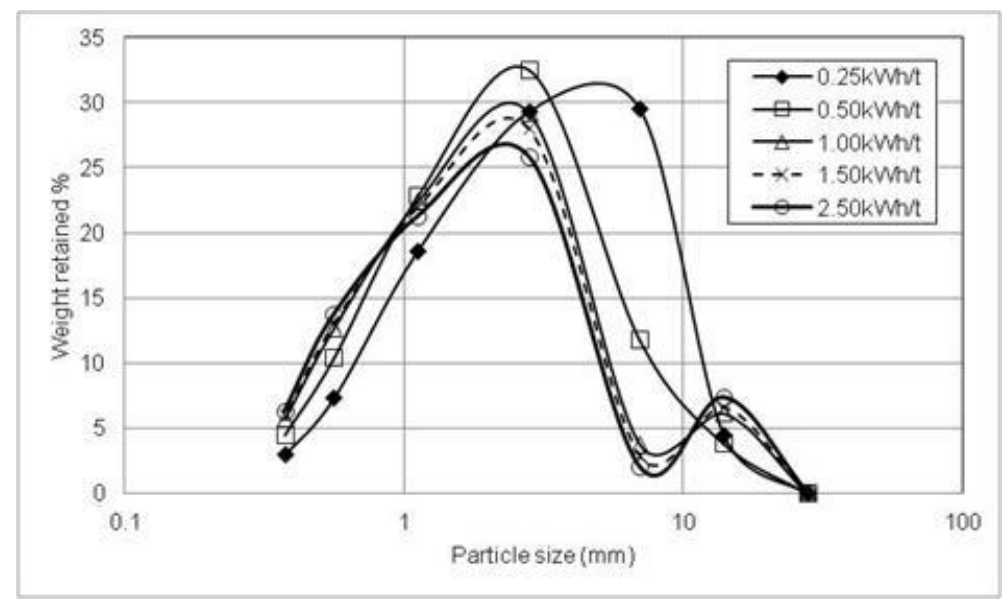

Figure 8. Typical impact breakage functions for different specific comminution energy levels

\subsection{Use of Breakage Function in Crusher Modelling}

The crushing process can be described by repetitive cycle of events. In this cycle, New feed entering the crusher is first classified. Later, very fine material by-passes breakage and reports directly to product. However, very coarse material reports directly to breakage. Intermediatesized material reports to breakage with a probability which increases with size. After breakage the classification process is repeated. The process is illustrated in Figure 9. 


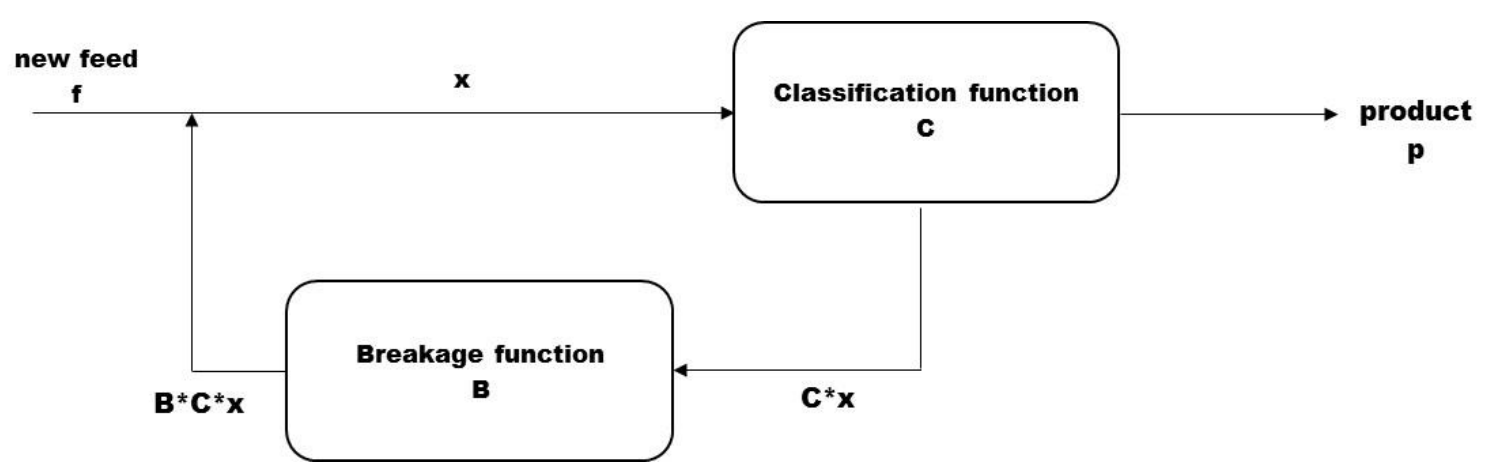

Figure 9. Schematic representation of the crusher model [3]

In the given model (Figure 9):

$\mathrm{x} \quad$ : a vector representing the amount in each size fraction in the crusher

f $\quad$ : feed size distribution vector

$\mathrm{p} \quad$ : product size distribution vector

C : classification or breakage selection matrix, describing the proportion of particles in each size interval selected for breakage

B : breakage distribution matrix, giving the relative distribution of each size fraction after breakage

The product size distribution vector is determined by the mass balance equation as given in Equation 3.

$$
p=(I-C)(I-B C)^{-1} f
$$

where I is the unit matrix. Unit matrix represents the total weight of unbroken particles which are leaving the crusher [32].

As stated in the literature, many crushers produce a geometric reduction in size because the crusher face moves a smaller distance jat finer gap sizes, that is, particles of different sizes undergo similar proportional size reduction when selected. A constant degree of reduction will produce a relatively constant t10 and product size distribution. Therefore when an ore has been characterised by a breakage test (such as the JKMRC pendulum or drop-weight test), it is only necessary to specify a t10 value to generate a product size distribution or breakage function [3].

It was claimed that, most brittle ores and quarry rocks break in crushers in a similar way unlike their behavior in SAG, AG and ball mills. Crusher breakage products can be represented by a single set of t-curves. Simulators use models to simulate many mineral processing equipments. The breakage function required in models of comminution equipments which are integrated in different simulators may be presented in different ways. The breakage data presented in this study specifically provided data to the JK Simmet Mineral Processing Simulator. Breakage function information is represented in the simulator by spline functions with the spline knots at t10 values of 10, 20 and 30\%. Derived breakage function data is presented for the colemanite ore in Table 4. Appearance function values can be used to 
estimate the full product size distribution of the jaw crusher using spline interpolation in the simulator [3].

Table 4. Appearance function derived for the colemanite ore for crusher models (JK Simmet Simulator Input Data)

\begin{tabular}{|c|c|c|c|c|c|}
\hline \multirow{2}{*}{$\begin{array}{c}\text { Breakage } \\
\text { parameter } \\
\mathrm{t} 10(\%)\end{array}$} & $\mathrm{t} 75$ & $\mathrm{t} 50$ & $\mathrm{t} 25$ & $\mathrm{t} 4$ & $\mathrm{t} 2$ \\
\cline { 2 - 6 } & 2.72 & 4.08 & 7.83 & 36.28 & 63.02 \\
\hline 10 & 4.04 & 5.86 & 10.71 & 51.89 & 81.44 \\
\hline 20 & 5.98 & 8.42 & 14.65 & 83.65 & 91.96 \\
\hline 30 &
\end{tabular}

\section{CONCLUSIONS}

Drop weight technique was used to demonstrate the size and energy level dependency of colemanite ore within a certain impact energy spectrum. Results indicated that, impact breakage of colemanite ore is size and energy level dependent which could be linked to the textural properties of the test size fractions. Ecs-t10 relationship and empirical t10-tn family curves were modelled and proposed to reconstruct breakage functions of colemanite ore which could be used in modelling of the jaw crusher.

\section{ACKNOWLEDGEMENTS}

Author would like to acknowledge to Prof.Ş.Levent Ergün from the Mining Engineering Department of Hacettepe University.

\section{REFERENCES}

[1] Narayanan, S.S. Development of a Laboratory Single Particle Breakage Technique and Its Application to Ball Mill Modelling and Scale-up, PhD Thesis. JKMRC, The University of Queensland, Australia, 1985.

[2] Brown, D., Grimes, A. Procedure for JKTech drop weight breakage test, JKTech Operating Manual, The University of Queensland, Australia, 2005.

[3] Napier Munn, T.J., Morrell, S, Morrison, R.D, Kojovic, T, Mineral Comminution Circuits Their Operation and Optimization. JKMRC Monograph Series in Mining and Mineral Processing, Australia, Brisbane: No. 2, The University of Queensland, 2005.

[4] Narayanan, S.S. Single particle breakage tests: a review of principles and applications to comminution modelling, Bull. Proc. Australas. Inst. Min. Metall., 291(4), 1986, p49-58.

[5] Narayanan, S.S. Modelling the performance of industrial ball mills using single particle breakage data, International Journal of Mineral Processing, 20, 1987a, p211228. 
[6] Kogel, E.J. Trivedi, C.N. Barker, M.J. Krukowski, T.S. Industrial Minerals and Rocks, $7^{\text {th }}$ Edition, Society for Mining, Metallurgy and Exploration, Inc. 2006.

[7] Weedon, D.M. A perfect matrix model for ball mills, Minerals Engineering, Permagon Pres.,14 (10), 2001, p1225-1236.

[8] Andersen, J.S. Development of a Cone Crusher Model, M.Eng.Sc. Thesis, The University of Queensland, JKMRC, 1988.

[9] Man, Y.T. A Model-based Scale-up Procedure for Wet, Overflow Ball Mills, PhD Thesis, JKMRC, Department of Mining, Minerals and Materials Engineering, The University of Queensland, 2000.

[10] Weichert, R. Herbst, J.A. An ultrafast load cell device for measuring particle breakage, Nürnberg: Proceedings, $1^{\text {st }}$ World Congress on Particle Technology, Part 2, 1986. p314.

[11] Fandrich, R.G. Clout, J.M.F. Bourgeois, F.S. The CSIRO Hopkinson Bar facility for large diameter particle breakage, Minerals Engineering, 11 (9), 1998, p861-869.

[12] Tavares, L.M. King, R.P. Single particle fracture under impact loading, International Journal of Mineral Processing, 12 (1), 1998, p43-50.

[13] Bourgeois, F.S. Banini, G.A. A portable load cell for in-situ ore impact breakage testing, International Journal of Mineral Processing, 65, 2002, p31-54.

[14] Austin, L.G. Luckie, P.L. Methods for determination of breakage distribution parameters, Powder Technology, 5, 1971/72, p215-222.

[15] Weller, K.R. Sterns, U.J. Artone, E. Bruchard, W.J. Multicomponent models of grinding and classification for scale-up from continuous small or pilot scale circuits, International Journal of Mineral Processing, 22, 1988, p119-147.

[16] Zhang, Y.M. Napier-Munn, T.J. Kavetsky, A. Application of comminution and classification modelling to grinding of cement clinker, Trans. IMM. 97: 1988, C207C214.

[17] Austin, L.G. Weller, K.R. Simulation and scale-up of wet ball mills. XIV International Mineral Processing Congress, Toronto, Canada: October 17-23, 1982, p8.1-8.24.

[18] Hukki, R.T. Proposol for a solomonic settlement between the theories of von Rittenger, Kick and Bond. Trans., S.M.E/A.I.M.E, 220, 1961, p403-408.

[19] Yashima, S. Kanda, Y. Sano, S. Relationships between particle size and fracture energy or impact velocity required to fracture as estimated from single particle crushing, Powder Technology, No.51, 1987, p277-282. 
[20] Schöenert, K. Fundamentals of Particle Breakage, Course Notes, Johannesburg: University of Witwatersrand, Division of Continuing Engineering Education, 1988, Section F6.

[21] Meloy, T.P. Preti, U. Locked particles three phase volume frequency distribution, Powder Technology, 71, 1992, p273-279.

[22] Awachie, S.E.A. Development of Crusher Models Using Laboratory Breakage Data, PhD Thesis, JKMRC, The University of Queensland, 1983.

[23] Leung, K. An Energy-based Ore Specific Model for Autogeneous and SemiAutogeneous Grinding, PhD Thesis, JKMRC, The University of Queensland, 1987.

[24] Narayanan, S.S. Lean P.J. Baker, D.C. Relationship between breakage parameters and process variables in ball milling-An industrial case study, International Journal of Mineral Processing, 20, 1987b, p241-251.

[25] Morrell, S. Man, Y.T. Using modelling and simulation for the design of full-scale ball mill circuits, Minerals Engineering, 10 (12), 1997, p1311-1327.

[26] Genç, Ö. Benzer, A.H. Ergün, Ş.L. Analysis of single particle impact breakage characteristics of raw and HPGR-crushed cement clinkers by drop weight testing, Powder Technology, 259, 2014, p37-45.

[27] Narayanan, S.S. Whiten, W.J. Breakage characteristics of ores for ball mill modelling, Proc. AusIMM, 286, 1983, p31-39.

[28] Narayanan, S.S. Whiten W.J. Determination of comminution characteristics from single particle breakage tests and its application to ball mill scale-up, Trans. Inst. Min. Metall. Sect. C, September, 1988, p115-124.

[29] Shi, F. Kojovic, T. Validation of a model for impact breakage incorporating particle size effect, International Journal of Mineral Processing, 82( 3), 2007, p156-163.

[30] Zhang, Y.M. Simulation of Comminution and Classification in Cement Manufacture, Ph.D. Thesis, South University B.E. (Central-South University of Technology), China, 1992.

[31] King, R.P. Modelling and Simulation of Mineral Processing Systems, Great Britain: Butterworth-Heinemann, 2001.

[32] Lynch, A.J. Mineral Crushing and Grinding Circuits, Their Simulation, Optimization, Design and Control, Elsevier Scientific Publishing Co., Amsterdam, 1977, p1-65. 


\section{CV}

\section{Ömürden GENÇ; Assistant Professor Dr.}

She received her BSc degree in 2000, MSc degree in 2002 and PhD degree in 2008 from Hacettepe University, Department of Mining Engineering, Turkey. She was employed as a research assistant during her postgraduate studies at Hacettepe University and as a research fellow at the Julius Kruttschnitt Mineral Research Centre, The University of Queensland (Australia) in 2008. She is currently employed as an Assistant Professor in the Department of Mining Engineering at Muğla Sitkı Koçman University (Turkey). Her research interests are in the fields of particle breakage characterization, particle sizing techniques, modeling and simulation of comminution circuits. 